\title{
Squealer or the Sophism Working for Modern Dictatorship: A Re-visitation of Orwell's Animal Farm
}

\author{
Armel Mbon $^{1 *}$, Benjamin Evayoulou ${ }^{2}$ \\ ${ }^{1}$ Lecturer-Researcher, Department of Languages and Literatures, Teachers Training College, Marien Ngouabi \\ University, Brazzaville, Congo \\ ${ }^{2}$ Professor, Department of Languages and Literatures, Teachers Training College, Marien Ngouabi University, \\ Brazzaville, Congo
}

*Corresponding Author: Armel Mbon, Lecturer-Researcher, Department of Languages and Literatures, Teachers Training College, Marien Ngouabi University, Brazzaville, Congo

\begin{abstract}
This article aims to revisit Orwell's use of Squealer, one of the leading pigs in Animal Farm, as a sophist, a linguistic propagandist given that propaganda comprises more than this. In the wake of the Russian Revolution, the author intervenes with the publication of this political allegory as a warning to the world of the dangers of dictatorship and totalitarianism. These regimes ruled and still rule in some parts of the world in a more or less disguised form thanks to people like Squealer, the embodiment of public speakers. Mussolini, Hitler, Franco and the like were themselves at a time dictators and speakers. But this paper tries to show that this heuristic and dialectic role falls today mainly on the press or ministers of communication who falsify truth for the sake of dictatorship. It shows moreover that the voice, body language and Aristotelian appeals are devices and methods to which Squealer has recourse to persuade his listeners. Indeed, to achieve its objective as regards the impact of Squealer's speeches, this analysis draws especially on the formalistic approach thereby resulting in the assessment of Squealer as the pillar of modern dictatorship.
\end{abstract}

Keywords: Allegory, Dictatorship, Re-visitation, Sophism, Squealer

\section{INTRODUCTION}

The indirect speech and the formality that characterises it, have often compelled storytellers to use animals in their stories. It is on this basis that allegory and fable have been created and come into use. By the end of World War II, George Orwell offered to English literature one of its best socio-political allegories: Animal Farm ${ }^{1}$. From Aesop to Orwell passing through La Fontaine, allegory has played a predominant role in our lives, a role that displays virtues as well as vices. News on the radio, television, newspapers, internet...are enough for us to realise that today in some parts of the world, people continue to live under a disguised dictatorship.

This leads us to state that the theme of dictatorship in Animal Farm is still topical as for Bradbury, this book "remains our great satire of the darker face of modern history" ( $A F$, back cover). When one tries to investigate modern political history, one realises that it is made up of sophists working for dictators around the world. So, arguing that Animal Farm is a clichéd work is a false assumption. In fact, according to Steadman, "Animal Farm has seen off all the opposition. It's as valid today as it was fifty years ago" ( $A F$, back cover). This validity gives us the incentive to re-visit this Orwell's political allegory in which he uses Squealer as Napoleon's right hand pig and spokesperson.

There is understandably no wonder if most criticism of this novella is targeted at politics. Such is the case of "Literature and Politics: A Review of George Orwell's Animal Farm and Chinua Achebe's A Man of the People" (2018) by Pelpuo, Bakuuro, and Tuurosong, a work in which the authors discuss the way Orwell and Achebe "satirise politics of their time and beyond" (PDF Source). We lay emphasis on "beyond" to highlight the topicality of Animal Farm. Mattson (2013), Jasim and Aziz (2013), Fadaee (2011), Pelissioli (2008) etc. view Squealer as a symbol of propaganda. Many are such

${ }^{1}$ Animal Farm is abbreviated in $A F$ for in-text referencing.

International Journal on Studies in English Language and Literature (IJSELL)

Page $\mid 48$ 
studies dealing with Squealer as a tool of propaganda of the Stalin era neglecting to focus on sophism, which, contrary to propaganda, feeds on occasion, adversity, and especially heuristic. By heuristic is meant the use of methods of argumentation to speed up the process of finding a satisfactory solution where finding an optimal solution is impossible or impractical. Therefore, Wykes (1987, p. 130) states that Squealer differs from the other leading characters of Animal Farm, since he does not solely represent events or concepts specifically tied to the Russian revolution or Stalin's rule. Mattson (2013, p. 15) adds that Squealer embodies the concept of propaganda and his functions can thus be applied to any form of government and polity.

Like Pelpuo, Bakuuro, and Tuurosong, most critics have demagogically approached Orwell's Animal Farm highlighting the gap between the privileged pigs and the underprivileged other animals thereby failing to emphasise language, which is the main element without which any political endeavour is effectless. One of the rare critics of Orwell's language in Animal Farm is, however, Elbarbary (1992), who has dealt with "Language as Theme in Animal Farm" in which he shows how language is manipulated as a tool to secure power. Of all these critical studies, Elbarbary's seems the closest to ours, insofar as a sophist has nothing but the language to defend dictatorship. Our departure from Elbarbary's lies, however, in our focus on the name, voice and rhetorical skills of or used by Squealer, the Sophist of Animal Farm. Language being the principal device for a sophist, how does Squealer use it in his public speeches and manage to be a successful worker for modern dictatorship?

Since Aristotle (1926, p. 36) teaches that a speaker's ability to persuade an audience is based on how well the speaker appeals to that audience, let us assume Squealer uses language persuasively resorting to three different areas or appeals: ethos, logos, pathos that make up the rhetorical triangle. Another assumption is that Squealer's voice and body are so dynamic that he performs these techniques of argumentation to perfection.

The different speeches Squealer delivers throughout this novella, are worth a discourse analysis, the analysis of features of language that extend beyond the limits of a sentence. Notwithstanding Squealer's aforementioned intent to defend dictatorship, the analysis of his discourse requires a formalistic approach whose Aristotle is one of the pioneers. Squealer's behaviour and his ability to probe into the minds of his fellow animals in order to appease and tame them for Napoleon, appeal to the psychoanalytical approach. There may be recourse to many other approaches because "any critic deserving of continued attention (...) is likely to employ that method - or better, those methods in combination - which best suit his knowledge, his particular critical sensitivities, and the work of art before him" (Scott, 1962, p. 11). This analysis is divided into two sections. While the first section deals with Squealer's name, voice and body language, the second and third will be devoted to Squealer's speech seen through Aristotle's rhetorical triangle including other techniques of argumentation used by Squealer.

\section{SQUEALER}

\subsection{Name and Voice}

Symbolically, Squealer is this pig who, in Animal Farm, represents the Soviet media, especially the well-known newspaper Pravda, which mainly functioned as a pro-communist tool of propaganda during Stalin's reign (Meyers 135). He is often associated with loyal Stalin supporter, Vyacheslav Molotov. Short and fat, Squealer is a terrific speaker who prioritizes his personal comfort above all else. Whenever the pigs violate the tenets of Animalism, Squealer persuades the other animals that the pigs are actually acting in everyone's best interest. In a dialogue most likely written in $360 \mathrm{BC}$, Plato defines a sophist as "an athlete in debate, appropriating that subdivision of contention which consists in the art of eristic (...) as a purifier of the soul from conceits that block the way to understanding." This definition of the sophist suits Squealer to perfection in accordance with his deeds. As any writer would do, Orwell introduces Squealer from the very start in these words:

All the other male pigs on the farm were porkers. The best known among them was a small fat pig named Squealer, with very round cheeks, twinkling eyes, nimble movements, and a shrill voice. He was a brilliant talker, and when he was arguing some difficult point he had a way of skipping from side to side and whisking his tail which was somehow very persuasive. The others said of Squealer that he could turn black into white. $(A F$, p. 9) 
From such an introduction we can straight infer that 'Squealer' means both eristic and a sophist. More than a mere word by which this pig is known, addressed, or referred to, the name 'Squealer' is characteristic of his whole being, referred to as his mind and body. Greenblatt (1974, p. 65) argues that this name sounds fairly pig-like but his actions do not. Taken figuratively, his name is also synonymous with betrayal towards the Farm animals through his role of Napoleon's mouthpiece. Not because he acts for money, but because he is "a lackey of Napoleon" (Mattson, 2013, p. 15).Inch (2016, p. 15) adds that "His [Squealer] name indicates that he is a person of less reliable character." In fact, in the wake of the Revolution and the freedom of Animal Farm from human domination, the leadership of the farm falls on the pigs. The animals think the Revolution has really set them free from humans. However, if they knew that their life was to be worse under the pigs than under human beings, they should not have rebelled against Mr. Jones and his men.

As a pig, Squealer carries with him bad connotations; he is ungrateful and untrustworthy in that along with other pigs, he violates the trust other animals have put on them as their leaders. This violation is besides evidenced in their corruption. In fact, the pigs corrupt the ideals of the Revolution to the point of resembling human beings. Napoleon, Squealer and the like turn out to be wolves in sheep's clothing to other animals. Their return to man's habits they have vomited is an expression of their uncleanness and corruption.

The name 'Squealer' does suit that pig known for the high-pitched sound that he makes during his screams. His extremely audible voice is first and foremost a major trump that he is qualified for that position, that of Napoleon's spokesperson. The voice of a character is heard through such elements as the words and punctuation used by the author. Squealer's voice has a profound influence on the mood and receptivity of his audience. Using his voice with animation and colour as a storyteller does, Squealer manages to charm his listeners. When he wants to sound friendly, warm, reassuring, intimate or caring when he speaks, he keeps his voice in a lower range with a lower pitch. As a public orator, Squealer is able to remind himself to slow down as it is very difficult to be close to one's listeners and thoughtful when one speaks too quickly. Public speakers tend to slow down naturally when they express out deeper emotions. When Squealer slows down his voice tone actually drops and becomes lower and more gentle as seen in Orwell's use of the adverb 'pleadingly' for Squealer's supplications:

Do you know what would happen if we pigs failed in our duty? Jones would come back! Yes, Jones would come back! Surely, comrades,' cried Squealer almost pleadingly, skipping from side to side and whisking his tail, 'surely there is no one among you who wants to see Jones come back?' (AF, p. 23)

On the other hand, Squealer picks up the tempo and uses the upper sound of his voice though not too high when he wants to sound exciting and energising. He varies his speed and tone like a driver who changes gears. He chooses well his pace and tone according to his subject and the mood he creates over his fellow animals. Deeper vocal sounds suggest size and strength. Really good speakers deliberately speak more slowly and with lower tone. They slow down and pause. This gives their words power, and people pay more attention to them.

The power of the pause is in fact one of the best known secrets of public speakers. In speaking, the drama or the power of the speech is contained in the silences that Squealer creates as he moves from point to point. When he is more relaxed, he speaks more slowly, and pauses regularly, he gains deeper and more authority with the tone of his voice. The pause grasps attention. When he pauses, his audience suddenly trip and fall in the silence he has created. The animals immediately give him back their full attention. Squealer uses the dramatic pause, which consists in making a particular point stick in the mind of the animals. This pause allows time for his audience to absorb. This is evidenced in the sentence, "Here Squealer's demeanour suddenly changed. He fell silent for a moment, and his little eyes darted suspicious glances from side to side before he proceeded" ( $A F$, p. 83).

A graphological glimpse of Squealer's voice shows a succession of exclamation and question marks that mostly reveal his false indignation towards his audience. In fact, when animals need some explanation about the disappearance of milk and apples, Squealer asks and exclaims. With such indignation, Squealer cannot choose but raise his voice so as to be heard and understood. The high pitch of his voice is thus clearly illustrated by the succession of these marks and Orwell's use of the verb "cry". This succession of punctuation in his speeches obviously justify his state of perpetual alarm through the novel. He has, however, no cause for alarm as seen in these words: 
'Comrades!' cried Squealer, making little nervous skips, `a most terrible thing has been discovered. Snowball has sold himself to Frederick of Pinch field Farm, who is even now plotting to attack us and take our farm away from us! (...) Snowball was in league with Jones from the very start! $(A F$, p. 53)

Squealer communicates not only with his voice, but also with his body. The body language is, as seen below, is a necessary complement for verbal language not only for the deaf and dumb, but also for those who do not understand the spoken communication.

\subsection{Body Language}

Famous public speakers like the Greek sophists, used verbal as well as nonverbal communication. So does Squealer, who communicates by word of mouth and body gestures. When he speaks his body becomes so dynamic that it helps him communicate efficiently. Orwell uses the collocation "skipping from side to side and whisking his tail" five times through the novel to show how Squealer's gestures help strengthen his message. A sophist's attitude in speech matters a lot as it contributes to breed success to his speech.In fact, the bad mood in which Squealer comes to apprise the animals of Snowball's plot against them, is a strong emotional appeal to their senses. Such an appeal, as it will be developed further down, is meant to frighten the audience for the purpose of strengthening a speaker's argument and convincing them that they have no other choice but to accept the speaker's views. We read thereupon that:

In the evening Squealer called them together, and with an alarmed expression on his face told them that he had some serious news to report (...) 'Comrades!' cried Squealer, making little nervous skips, ‘a most terrible thing has been discovered. Snowball has sold himself to Frederick of Pinchfield Farm, who is even now plotting to attack us and take our farm away from us! (AF, p. 53)

Emotions such as an alarmed expression on the face are all the more affective that they are easily transmitted to one's audience. Just on the emotional plan, such alarmed expressions often break the heart and thus make room to tears, for instance on the announcement of Boxer's death for which the Farm animals shed many tears. Theirs are not crocodile tears as those shed by Squealer when he comes to announce these sad news, "He had, he said, been present during Boxer's last hours. 'It was the most affecting sight I have ever seen!' said Squealer, lifting his trotter and wiping away a tear" $(A F$, p. 83).

A public speaker's voice and body express some appeals that, to be better understood, need a look back in the past when this art of public speaking was ancient Greek custom.

\section{SQuealer's SPEech as a RHETORICAL TRIANGLE}

Public speaking was an art in vogue long before the Greek writers devoted their energy to it more than 2,500 years ago. It was the Greek men's way of life. We remain indebted to the ancient Greeks because they paved the way for the art of persuasive speaking or writing, which they called "rhetoric" and which most politicians use today. One of those pioneers of rhetoric was Aristotle, a Greek philosopher who lived in the 4th century BCE. He was an influential thinker and wrote on many subjects - from logic and ethics, to biology and metaphysics, but he was particularly interested in rhetoric. He even wrote a whole book entitled 'On Rhetoric' in which he explains his theories of persuasive language and speech.

Most significantly, in this work he expounds on the concepts of ethos, logos and pathos, as tools for persuasive language. Each type of rhetoric employs these three appeals of the rhetorical triangle, also called the Aristotelian Triad or Rhetorical Triangle. They appeal to authority, logic, and emotion. They are respectively arguments in which the speaker like Squealer either claims to be an expert or relies on information provided by experts, attempts to persuade the listener through use of deductive reasoning, or attempts to affect the listener's personal feelings.

\subsection{Ethos}

In Animal Farm, registers of persuasion are abundantly used by Squealer. By using ethos, Squealer does not claim to be an expert, but rather relies on information provided by experts, which is an appeal to authority. By quoting scientists, Squealer throws off the burden of responsibility thereby 
disapproving of the pigs' guilt in the mysterious disappearance of milk and apples. This is a way for him to make excuses on behalf of all the pigs and take the animals' mind off to the universal truth of Science. The passage reads that all the pigs were in full agreement on this point, and Squealer was sent to make the necessary explanations to the others:

'Comrades!' he cried. 'You do not imagine, I hope, that we pigs are doing this in a spirit of selfishness and privilege? Many of us actually dislike milk and apples. I dislike them myself. Our sole object in taking these things is to preserve our health. Milk and apples (this has been proved by Science, comrades) contain substances absolutely necessary to the well-being of a pig. We pigs are brainworkers. The whole management and organisation of this farm depend on us. Day and night we are watching over your welfare. It is for your sake that we drink that milk and eat those apples. ( $A F$, p. 23$)$

\subsection{Logos}

Logos is the most used appeal of Sophists in that everything turns round the language. Sophists manage to make their arguments logic. Given that in sophism there is a speaker's obvious will to deceive the audience, truth is distorted for the sole purpose of besmirching the opponent's good reputation as Napoleon's pawn Squealer does against his enemy Snowball. Inch (2016, p. 15) argues, "Squealer is the true rhetoricist and orator in the book. His language, means of persuasion and manipulation ensure that all the other animals are kept under sway. He even goes as far as to falsify truths, memories and the commandments." In fact, as a politician, he draws his listeners' attention by scapegoating Snowball. It reads that:
Afterwards Squealer was sent round the farm to explain the new arrangement to the others. 'Comrades,' he said, 'I trust that every animal here appreciates the sacrifice that Comrade Napoleon has made in taking this extra labour upon himself. Do not imagine, comrades, that leadership is a pleasure! On the contrary, it is a deep and heavy responsibility. No one believes more firmly than Comrade Napoleon that all animals are equal. He would be only too happy to let you make your decisions for yourselves. But sometimes you might make the wrong decisions, comrades, and then where should we be? Suppose you had decided to follow Snowball, with his moonshine of windmills -- Snowball, who, as we now know, was no better than a criminal?'
'He fought bravely at the Battle of the Cowshed,' said somebody. 'Bravery is not enough,' said Squealer. 'Loyalty and obedience are more important. And as to the Battle of the Cowshed, I believe the time will come when we shall find that Snowball's part in it was much exaggerated. Discipline, comrades, iron discipline! That is the watchword for today. One false step, and our enemies would be upon us. Surely, comrades, you do not want Jones back?' ( $A F$, p. 37)

In the sentence "Bravery is not enough (...) Loyalty and obedience are more important", we realise that Squealer is using concession, a technique of argumentation consisting in accepting at least part or all of an opposing viewpoint. This technique is often used to make one's own argument stronger by demonstrating that one is willing to accept what is obviously true and reasonable, even if it is presented by the opposition. Sometimes, however, a concession is immediately followed by a rebuttal of the concession. In fact, when Squealer says that bravery is not enough it means that he does not totally reject the viewpoint, but does not value it as he values loyalty and obedience. To obey Napoleon, for him, is better than sacrifice oneself for Animal Farm. This rebuttal of the concession is in other words, a correction of erroneous views, that is, Squealer manages to point out where these observations about Snowball's bravery at the Battle of the Cowshed, needs modification or correction.

As a sophist, his purpose is to brainwash the animals into letting them believe that the windmill was Napoleon's own creation. One notices that whenever there is opposition in the audience to his views, he changes strategies. As a good dialectician, he first concedes, and then refutes the point. It is written that:

That evening Squealer explained privately to the other animals that Napoleon had never in reality been opposed to the windmill. On the contrary, it was he who had advocated it in the beginning, and the plan which Snowball had drawn on the door of the incubator shed had actually been stolen from among Napoleon's papers. The windmill was, in fact, Napoleon's own creation. Why, then, asked somebody, had he spoken so strongly against it? Here Squealer 
looked very sly. That, he said, was Comrade Napoleon's cunning. He had seemed to oppose the windmill, simply as a manoeuvre to get rid of Snowball, who was a dangerous character and a bad influence. Now that Snowball was out of the way, the plan could go forward without his interference. This, said Squealer, was something called tactics. ( $A F$, pp. 38-39)

Whether they are additions or subtractions, amendments to an ideology whatsoever are not forcibly a bad thing. In fact, since their addition to the American Constitution the Ten Amendments have proved themselves. What is wrong is the intentional distortion of the ideology for the sake of wrongdoing. The completion of the Fourth Commandment of Animalism (a complete system of thought elaborated from Old Major's teachings by three pigs Snowball, Napoleon, and Squealer) with "with sheets", is an intentional addition in order to privilege pigs to the detriment of other animals. It is amazing how Squealer's definition of a bed is. In the passage below, from the addition of sheets to their substitution by blankets, Squealer lies on all the line thereby proving a modern sophist:

'It says, 'No animal shall sleep in a bed with sheets," she announced finally. Curiously enough, Clover had not remembered that the Fourth Commandment mentioned sheets; but as it was there on the wall, it must have done so. And Squealer, who happened to be passing at this moment, attended by two or three dogs, was able to put the whole matter in its proper perspective.

'You have heard then, comrades,' he said, 'that we pigs now sleep in the beds of the farmhouse? And why not? You did not suppose, surely, that there was ever a ruling against beds? A bed merely means a place to sleep in. A pile of straw in a stall is a bed, properly regarded. The rule was against sheets, which are a human invention. We have removed the sheets from the farmhouse beds, and sleep between blankets. And very comfortable beds they are too! But not more comfortable than we need, I can tell you, comrades, with all the brainwork we have to do nowadays. ( $A F$, pp. 45-46)

By defining a bed otherwise, Squealer uses another technique of argumentation called counter example, which is an example that runs counter to a generalisation, thus falsifying it. Discovering that pigs sleep in beds with sheets is quite an incident in the farmhouse. However, to minimise the incident, Squealer negates the advantage that blankets could have in comparison with other bedclothes. In reading his definition of a bed, we may suspect Squealer begs the question as he sidesteps or evades the real problem, which is bedding or material for animals to sleep on. Along with other pigs, Squealer revises not only the commandment linked to sleeping, but also those linked to drinking and killing in order to clear them of accusations of law-breaking (such as "No animal shall drink alcohol" having "to excess" appended to it and "No animal shall kill any other animal " with "without cause" added to it).

As can be seen above, Squealer's speeches contain rhetorical questions, meant not to be answered, but to monopolise the floor and then floor the Farm animals. This series of questions from Squealer are either unanswered or answered by himself. The Farm animals are, to borrow the words of Brown (1981, p.30), "seldom shrewd, and can be disheartened and deceived by cunning people with quick tongues." A patent example of such cunning people with quick tongues is Squealer. The reading of Animal Farm shows that whenever Squealer cannot convince his audience with ethos and logos, he appeals to emotion or fear in the last resort.

\subsection{Pathos}

The appeal to emotion or fear is known as pathos. Squealer handles this appeal with ease. His flowing style includes bandwagon, an attempt to strengthen an argument by convincing the audience that accepting the speaker's view will put the animals on the popular or apparently winning side, and ad hominem, a Latin phrase for "against the man". In fact, Squealer personally attacks Snowball instead of his arguments. As can be seen in the speeches below, his attack appeals to emotion rather than reason, feeling rather than intellect. In doing so, he does not refrain from brandishing the spectre of Jones in most of his speeches. Pathos appears in Squealer's clarification of the circumstances of the disappearance of milk and apples ( $A F$, p. 23).

On the one side, Squealer makes a scapegoat of Snowball, and on the other, brandishes the spectre of Jones, who may come back for more with Snowball's conspiracy. More than three times he repeats "Jones back" such as One false step, and our enemies would be upon us. Surely, comrades, you do not 
want Jones back?' ( $A F$, p. 37$)$ and "You would not have us too tired to carry out our duties? Surely none of you wishes to see Jones back?" ( $A F, \mathrm{pp} .45-46)$. The dread of Jones after his overthrow, that terrible master from whose rule no animal wants to return, makes them rather bear those ills they have under Napoleon than fly to others that they know not of.

Not only does Squealer associate Snowball with Jones, he also associates him with Frederick, the owner of Pinchfield Farm (AF, p. 53). This is, as every reader of Orwell's Animal Farm knows, a mere slanderous statement on Snowball. It is, instead, Napoleon, who is in cahoots with Frederick from whom he gets alcohol in exchange of Boxer, one of the most loyal workers on the farm. On the announcement of Boxer's death, it is written that:

After about a quarter of an hour Squealer appeared, full of sympathy and concern. He said that Comrade Napoleon had learned with the very deepest distress of this misfortune to one of the most loyal workers on the farm, and was already making arrangements to send Boxer to be treated in the hospital at Willingdon(...) Squealer easily convinced them [animals] that the veterinary surgeon in Willingdon could treat Boxer's case more satisfactorily than could be done on the farm. $(A F$, p. 80$)$

Squealer adapts to the circumstance of the announcement of this piece of sad news. His speech is so pathetic that it is likely to be believed by the animals. Good speakers often tend to transmit their emotions to the audience. If Squealer cannot transmit his, his body language and his pause make his account most convincing. His speech, which appears like an appeal to patriotism, is in fact, an appeal to the cult of Napoleon's personality. As one reads the words below, one realises that Squealer is a born liar:

'It was the most affecting sight I have ever seen!' said Squealer, lifting his trotter and wiping away a tear. 'I was at his bedside at the very last. And at the end, almost too weak to speak, he whispered in my ear that his sole sorrow was to have passed on before the windmill was finished. 'Forward, comrades!' he whispered. 'Forward in the name of the Rebellion. Long live Animal Farm! Long live Comrade Napoleon! Napoleon is always right.' Those were his very last words, comrades.'

Here Squealer's demeanour suddenly changed. He fell silent for a moment, and his little eyes darted suspicious glances from side to side before he proceeded (...)

The animals were enormously relieved to hear this. And when Squealer went on to give further graphic details of Boxer's death-bed, the admirable care he had received, and the expensive medicines for which Napoleon had paid without a thought as to the cost, their last doubts disappeared and the sorrow that they felt for their comrade's death was tempered by the thought that at least he had died happy. (AF, pp. 83-84)

If ethos, logos, and pathos respectively relate to authority, logic, and emotion, kairos, which is the Greek for "right time," "season," "timeliness" or "opportunity", is an opportunity given to Squealerto deliver his speeches without protest from the audience. Orwell shows that squealer often delivers his speeches in the evening time $(A F$, pp. 38-39; p. 53) or on Sunday mornings $(A F$, p. 50$)$. The choice of these adverbial clauses is very significant in that evening time and Sunday mornings are respectively moments when people's minds are already appeased by the falling sun, and when they rise with the idea of praying God. In such circumstances there cannot be any protest at all.

\section{CONCLuSion}

The question of this research being to know how Squealer uses language in his public speeches and how he manages to be a successful worker for modern dictatorship, this work was carried out on the assumption that he uses language persuasively resorting to three different areas or appeals: ethos, logos, pathos that make up Aristotle's rhetorical triangle. Also, Squealer's voice and body are so dynamic that he performs these techniques of argumentation to perfection. Through the preceding lines it becomes clear that he prevents the Farm animals, in spite of their discontent, from rebelling against the pigs.

Squealer's different speeches are a clear example of propaganda which is a form of persuasion used to influence the Farm animals in virtual life, but people's attitudes, beliefs, and behaviors in real life. This has been obvious with the corruption of Animalism from which the pigs elevate themselves 
above their equals. If modern dictators in the persons of Orwell's famous characters, Napoleon and lately Big Brother in 1984, use all the media available to spread their hegemony, the main embodiment of all this is Squealer. At the time when political leaders hunger for staying in power in countries where constitutions are made to measure, Squealer shoots up from the ranks in the persons of and spokespersons for the governments. As such, he stands for all those past and present-day ministers of communication around the world that are not nominally mentioned here.

\section{REFERENCES}

[1] Aristotle. The Art of Rhetoric. Ed. John Henry Freese. London: William Heinemann. New York: G.P. Putnam's Sons, 1926.

[2] Brown, Suzanne. York Notes on Oliver Twist. eds. A.N. Jeffares, and Suheil Bushrui. Harlow: Longman Group Ltd., 1981.

[3] Elbarbary, Samir. "Language as Theme in Animal Farm." The International Fiction Review. 19.1 (1992): $31-38$.

[4] Fadaee, Elaheh."Symbols, metaphors and similes in literature: A case study of Animal Farm." Journal of English and Literature Vol. 2(2), 2011, pp. 19-27.

[5] Greenblatt, Stephen. "Orwell as Satirists." Class Culture and Social Change. Sussex: Harvester Press, 1974, pp. 56-90.

[6] Inch, James. "Communism and the betrayal of the revolution: a Marxist critique of the post-revolutionary manipulation of the proletariat in Animal Farm", 2016. PDF Source.

[7] Jasim, H. Majeed and, Fatima H. Aziz. "Propaganda in George Orwell's Animal Farm: An Allegorical and Satirical Study." Journal of the College of Arts. University of Basrah. No. (66) 2013 PDF Source.

[8] Mattson,B. Alexander. "The Unraveling of Orwell's Puzzle: A Literary Analysis of the Characters in George Orwell's Animal Farm." (2013), PDF Source.

[9] Meyers, Jeffrey. A Reader's Guide to George Orwell. London: Thames and Hudson Limited, 1975.

[10] Orwell, George. Animal Farm. (First published 1945), London: Penguin Books, 2008.

[11] Pelissioli, Marcelo. "From Allegory into Symbol: Revisiting George Orwell's Animal Farm and Nineteen Eighty-Four in the Light of $21^{\text {st }}$ Century Views of Totalitarianism." 2008, PDF Source.

[12] Pelpuo, H. Rashid, Justine Bakuuro, and Damasus Tuurosong. "Literature and Politics: A Review of George Orwell's Animal Farm and Chinua Achebe's A Man of the People." International Journal of English Language and Linguistics Research, Vol.6, No 2, (April 2018), pp. 1-26.

[13] Scott, Wilbur. Five Approaches to Literary Criticism: An Arrangement of Contemporary Critical Essays. London: Collier-Macmillan Ltd., 1962.

[14] Wykes, David. A Preface to Orwell. London: Longman Group Limited, 1987.

Citation: Armel Mbon, Benjamin Evayoulou. “ Squealer or the Sophism Working for Modern Dictatorship: A Re-visitation of Orwell's Animal Farm "International Journal on Studies in English Language and Literature (IJSELL), vol 7, no. 1, 2019, pp. 48-55. doi: http://dx.doi.org/10.20431/2347 -3134.0701006

Copyright: ( $) 2019$ Authors. This is an open-access article distributed under the terms of the Creative Commons Attribution License, which permits unrestricted use, distribution, and reproduction in any medium, provided the original author and source are credited. 